\title{
MARIJA CSERNYAK \\ A digitális korszak orosz prózairodalmának tendenciái: az interaktív irodalom kérdéséhez
}

A modern digitális világ kihívásai, a kor rohamosan változó szociokulturális paraméterei és általában a kultúra, azon belül pedig az irodalom fejlődésének új pályája mind az írói, mind az olvasói elemző eszköztár megújítását követelik. Mihail Epstejn a humántudományok jövőjéről gondolkodva egy gyakorlati és kísérleti jellegü irodalomtudományról beszél, amelynek mintáit megtalálhatjuk azoknál az íróknál, kritikusoknál és gondolkodóknál, akik lefektetik az irodalom új irányainak alapjait, vagy akik az új müvészi formák lehetőségeit kutatják. „Törekvéseik területe már nem csupán a poétika és az esztétika, amelyek az irodalom és a művészet érvényben lévő törvényeit kutatják, hanem a transzpoétika és transzesztétika, amelyek az irodalom és a művészet új lehetőségei felé mozdulnak el, és megpróbálják átalakítani azt, amit kutatnak." ${ }^{\prime}$ Epstejn joggal veti fel, hogy

az irodalomtudományban a három általánosan elfogadott terület: az irodalomelmélet, az irodalomtörténet és az irodalomkritika mellett helyet kell kapnia a projekciós tevékenységnek is: az új szövegstratégiák, módszerek, müfajok, irányzatok megalapozásának. Az irodalomtudománynak szüksége van egy negyedik területre, amely nem a múltra (irodalomtörténet), nem a jelenre (irodalomkritika) és nem az örökérvényüre (irodalomelmélet) irányul, hanem az irodalom jövőjére (prognosztika, heurisztika, kreatorika). ${ }^{2}$

$\mathrm{Az}$ angol író, Neil Gaiman az egyik író-olvasó találkozón így élezte ki az e-kultúra problémáit:

Az utóbbi években elhagytuk az információhiányt, és megérkeztünk az információtelítettséghez. A Google-os Eric Schmidt szerint az emberi faj manapság minden két nap alatt annyi információt hoz létre, amennyit a civilizáció kezdete óta 2003-ig állítottunk elő. Ez olyan napi öt exabájt amennyiben szeretik a számokat. A feladat ma nem az, hogy megtaláljunk egy kósza virágot a sivatagban, hanem hogy felkutassunk egy konkrét növényt a dzsungelben. Szükségünk van segítségre a navigálásban, hogy eb-

\footnotetext{
${ }^{1}$ Mihail Epstejn, Buduscseje gumanyitarnih nauk: Tyehnogumanyizm, kreatorika, erotologija, elektronnaja filologija i drugije nauki 21. veka, Moszkva, PINOL klasszik, 2019, 11.

${ }^{2}$ Uo., 12.
} 
ben az információmennyiségben megtalálhassuk azt, amire valóban szükségünk van. ${ }^{3}$

Valóban, az e-kultúra új szintre helyezte az emberiséget és létrehozta a digitális tartalmak, a virtualitás, az új tér-idő, a nyelv, a kommunikációs formák szféráját. Az e-kultúrát tanulmányozva a filozófusok megjegyzik:

Az e-kultúra lehetővé teszi az embernek, hogy felfedezze a létezés még egy formáját, amely, mivel összekapcsolódik az információs technológiákkal, minőségileg új jelenségként mutatkozik meg - sajátos „harmadik természetként”, amely a létezés természetes közege és a „tárgyi világ” után következik. Ahhoz hasonlóan, ahogyan a mikroszkóp vagy a teleszkóp felfedezése új világokat tárt fel a kutatók előtt, ugyanígy az IT-technológia is új „élettereket” nyitott meg a „felhasználók” számára. Ennek a világnak kialakultak a maga törvényszerüségei, szabadságai és jogai, a maga terminusai, szerzői, fogyasztói és kifejezésformái. ${ }^{4}$

Ilyen új kifejezésformákat ötlenek ki és hagynak jóvá folyamatosan a kortárs írók. Így például nemrégiben Dmitry Glukhovsky, a Metró 2033 és még néhány kötetnyi folytatása, valamint $A$ jövő és a Text címü könyvek szerzője audio sorozattal lépett elö, és a Storytel cég számára megírta a posztapokaliptikus Jaroszlavl és lakói történetét. Az orosz irodalom története során elöször fordult elö, hogy egy regény - a Poszt - audio könyv formájában jelent meg elöször.

A modern világban a virtuális világ az irodalom ideális közegének tekinthetö, amennyiben a szépirodalmi szövegek alkotási folyamatainak, népszerüsítésének és további megvitatásának széles spektrumát sorakoztathatja fel. A 21. században az Internetet nyugodtan nevezhetjük az irodalmi élet új központjának, amelynek hálózati terében szépirodalmi müvek jönnek létre. Ha a net-irodalom hajnalán az egyik kritikus, Szergej Kornyev - aki e jelenség jövőbeni alakulását hipotetikusan úgy fogalmazta meg, mint nyitott klubot, vagy mint egy 18. századi szellemben müködő nagyvilági irodalmi szalont - azt írta, hogy az új olvasó kinevelésének feladata nemcsak abban áll, hogy a net-irodalom „megkövetelje magától, hogy fent legyen az Interneten, hogy kirakja az Internetre alkotása termékeit, hanem hogy áthelyezze az Internetre magát az irodalmi életet, hogy nyitottá és átláthatóvá tegye, valóságos vonzásközpontokat hozzon rajta létre, amelyek körül valóban forrjon az élet", ${ }^{5}$ akkor húsz év elteltével

\footnotetext{
${ }^{3}$ Neil Gaiman, Umnije ljugyi csitajut hudozsesztvennuju lityeraturu. https://lifedeeper.ru/post/3776gejman-nil-umnye-ljudi-chitajut-hudozhestvennuju-literaturu/ (Letöltés ideje: 2020. április 15.)

${ }^{4}$ L. V. BAJEva, Elektronnaja kultura: opit filoszofszkovo analiza, Voproszi Filoszofiji, 2013/5, 76. - Vö. Szergej KORNYEv, „Szetyevaja lityeratura” i zaversenyije posztmoderna: Internet kak meszto obitanyija lityeraturi. https://www.netslova.ru/kornev/kornev.htm (kiemelés az eredetiben) (Letöltés ideje: 2020. április 15.)

${ }^{5}$ Kornyev, i. m.
} 
világossá vált, hogy a Web 2.0 forradalma nem egyszerüen csak a web-oldalak létrehozásának és a szociális hálózatok szervezésének módszereit érintette, hanem az irodalom természetét is.

A net-irodalom, amely „múzsának és médiumnak a digitális közeg transzmediális lehetőségeit” használja, felkínálja az olvasónak annak lehetőségét, hogy a szerző által jóváhagyott szabályok szerint önállóan konstruálja meg a szöveget, amennyiben a szerző a mủ alkotója és kontrollálja a cselekmény menetét. Az olvasó, aki felruházódik a szövegalkotó bizonyos vonásaival, „álszerzőve’” válik. Következésképpen, a hagyományos, nyomtatott irodalomtól eltérően a net-irodalom szélesebb lehetöségeket kínál az olvasónak, miközben azért megtartja a klasszikus szépirodalmi szöveg bizonyos jellegzetességeit is. Azok a lehetőségek, amelyeket az internetes közeg kínál, őt magát az interaktív irodalmi műfajok, a legkülönfélébb irodalmi játékok és a kollektív alkotás (a hipertextuális belletrisztika kollektív létrehozása, az interaktív versalkotási játékok, a „virtuális színházzá” alakuló csoportos szóbeli performansz, stb.) ideális helyévé teszik.

Mihail Epstejn véleménye szerint a net-irodalom már

posztirodalmi korszak, amelyben a szó visszakapja ugyanazt a mozgékonyságot és plasztikusságot, mint ami a szóbeli létezési módjában megvan. Az interpretáció mint filológiai procedúra jelentősége csökken, mivel a szöveg kritikája performatívvá válik. Ahelyett, hogy értelmeznénk, értelmét a szükségleteinkre, a pillanatnyi követelményekre alkalmaznánk, egyszerübb megváltoztatnunk. [...] A szöveg értelme pulzál, miközben különféle jelkonfigurációkat alkot. A mély szemantikát a szöveg dinamikája váltja fel. Az értelem szemantikai kategóriából szintaktikaiba fordul. Míg korábban az értelmi gazdagság a szövegen kívülre, a jelölők szférájára projektálódott, addig most a mozgásban lévő szövegkörnyezetére, azoknak a kereteknek, frémeknek, jelformációknak változására, amelyben állandóan változtatja az értelmét.?

A net-irodalom, amely az elmúlt húsz évben a szemünk láttára fejlődik, egyre provokálja a filológusokat, filozófusokat, kultúrantropológusokat, a digitális humántudományok szakembereit, hogy sajátos terminológiai apparátust dolgozzanak ki. „A filológia minden alapvető fogalma - »olvasás«, »írás«, »szöveg «, »interpretáció« - új értelmet nyer a digitális világegyetemben, és azonnal új terminológiai artikulálást is követel"8 - jegyzi meg Epstejn. M. Baszova a szépirodalmi szöveg, többek között a virtuális szöveg egyik kulcsfontosságú jellemzőjének az „endoforikussága” (vagyis a szerzö-alkotótól való elkülönülése) és „poszttemporalitása” (a szöveg létrehozása és befogadása közötti időbeli distancia megléte) vonatkozásában megmutatkozó

\footnotetext{
${ }^{6}$ A. Guld, Esztyetyika i pedagogika elektronnoj lityeraturi, Novoje lityeraturnoje obozrenyije, 2012, 115. szám, 327.

${ }^{7}$ Epstejn, i. m., 57.

${ }^{8}$ Uo., 16.
} 
rögzítettségét tartja. ${ }^{9}$ Ezzel szemben Mihail Epstejn azt javasolja, hogy az e-szöveget „textoidnak”, „mintha-szövegnek” nevezzük (textoid - a text szóból és a görög „oid” [valaminek a hasonlatára] utótagból, amely az „eidos” [képmás] szóra megy vissza). Az ilyen szöveg híján van a rögzítettségnek, szabadon változtatja formáját és kontextusát, amikor egyik felhasználótól a másikhoz kerül. A textoidok tág teret nyitnak a digitális jelformációk kritikai olvasása-átírása új módozatai előtt. ${ }^{10}$

Számításba kell venni, hogy a digitális tér nyújtotta lehetőségek elősegítik azt is, hogy a virtuális irodalom eltávolodjon az egyenes vonalú cselekményvezetéstől és a narrativitástól: a net-irodalom „bizonyos részben ergodikussá válik (Espen Aarseth terminusa), amely nem-lineáris módon épül fel, és amelynek vonalvezetését az olvasó adja meg a szerző által megtervezett cselekményszálak variativitása alapján". ${ }^{11}$ E metamorfózisok következményeképpen a narrativitást interaktivitás („az olvasó és a szöveg játékos egymásra hatása") váltja fel. Ily módon kiemelhetünk néhány kulcsfontosságú tulajdonságot, amelyek jellemzők a net-irodalomra: intertextualitás, hipertextualitás, pluralizmus, polidiszkurzivitás és multimedialitás.

Külön figyelmet érdemel annak az interaktív irodalomnak fejlődése, amely klasszikus irodalmi szöveget, illusztrációkat, hipertextust, komputeres játékok elemeit és multimediális technológiákat (video- és audiósorokat) foglal magában. Interaktív könyvek elsőként még 2010-ben bukkantak fel az amerikai piacon, és ez az Apple iPad megjelenésével áll összefüggésben. Az interaktív regény olyan szépirodalmi alkotás, amelynek szövege nem-lineárisan épül fel, és amely az olvasó reakciójától és kívánságától függöen változhat. Az ebbe a müfajba tartozó regények rendszerint több cselekményszállal, kulminációs ponttal és befejezéssel rendelkeznek. Az interaktív mű teljes szüzséje az olvasás folyamatában bontakozik ki és különféle transzformációkon eshet át. Az interaktív könyvet, a komputeres játékhoz hasonlóan, minden egyes alkalommal „másféleképpen" lehet olvasni - minden a befogadó választásától függ.

Nyilvánvaló, hogy a kortárs orosz irodalom az Interneten a legkülönfélébb eredeti vonásokra tett szert, amelyek tükrözik a netes gondolkodás sajátosságait és az irodalmi folyamat aktuális tendenciáit. Oroszországban a legkifejlettebbnek a papíralapú, interaktív „játék-könyv” műfaja tekinthetö, amelyben a szöveg „nagyszámú számozott blokkokra, úgynevezett "paragrafusokra« van felosztva, és az olvasó - egy sor könyvről könyvre változó, de elöre lefektetett szabály alapján - mozoghat különféle variációk szerint a paragrafusok között, befolyásolva közben a történet menetét. Ily módon változhat a szereplők jelleme és sorsa, a bonyodalom és a megoldás". ${ }^{12} \mathrm{Az}$

\footnotetext{
${ }^{9}$ M. V. BAszova, Szetyevaja lityeratura:problema esztyetyicseszkoj konceptualizacii= M. V. B., Isztoricseszkije, filoszofszkije, politicseszkije i jurigyicseszkije nauki, kulturologija i iszkussztvovegyenyije: Voproszi tyeoriji $i$ praktyiki, Tambov, 2015, 23-24.

${ }^{10}$ Epstejn, i. m., 32.

${ }^{11}$ Baszova, i. m., 23-24.

12 G. Loginov, Knyigi-igri i interaktyivnije romani. http://pisateli-za-dobro.com/knigi-igry-iinteraktivnye-romany.html. (Letöltés ideje: 2020. április 15.)
} 
interaktív regény müfajában készült egyik legfrissebb és legjellegzetesebb munka Borisz Akunyin Octopus projektje. „Az Internet az »élő szövegek fellelhetési helye. Az olyan szövegeké, amelyek mozgásban vannak, képekké alakulnak, mozgatják vesszöiket és egyéb írásjeleiket" - írta a net-irodalomról még az orosz net-irodalom kibontakozásának kezdetén a posztmodern irodalomkritikus, Vjacseszlav Kuricin. ${ }^{13}$

Borisz Akunyin müvészete szimptomatikus jelenség a kortárs irodalomban, mivel megjelenése és további alakulása pontosan kijelöli azt a fó csapást, amely az irodalom fabuláris gyengeségének leküzdésére irányul. Akunyin regényei a 19-20. század fordulójának stilizált világára épülnek, amelyre jellemző az esztétikai befogadás funkciójának változása, miközben a mü gyakran helyeződik át egyik münemi-müfaji regiszterből a másikba. Ugyancsak jellemzők rá a változatos müfaji transzformációk és egy újfajta diskurzus kialakítása is. Akunyin szereti meglepni magát a kerek évfordulóira. Az ötvenedik születésnapjára az FM című regénnyel lepte meg magát, az első olyan regénnyel, amely kilépett a papíralapú kiadás keretei közül a net-irodalomba. A hatvanadik születésnapján pedig bemutatta a blogján az Octopus projekt interaktív könyveinek tervezetét.

A projekt első könyve a Szulazsin című kisregény. Az Octopus szerzője a következőképpen írja le elgondolását:

A Szulazsin - irodalmi játék, amelyben a legfontosabb dolog az olvasótól függ. Első fejezetének egy variánsa van, és szabadon hozzáférhető. Ha a felütés számot tartott az érdeklődésére, választania kell: olvassa-e tovább, vagy sem, és ha igen, akkor melyik úton megy tovább. Tulajdonképpen minden ugyanúgy történik, mint az életben. Az első szakaszban helyettünk döntenek, aztán pedig már mi magunk döntünk, és hogy végül hová jutunk, a paradicsomba-e vagy a pokolba, a saját cselekedeteinktől függ. És ne ijedjenek meg a komor kezdéstől. Nem minden végződik rosszul, ami rosszul kezdődik. ${ }^{14}$

Mindenképpen emlékeztetnünk kell rá, hogy olyan irodalmi projekttel van dolgunk, amely kizárólag a neten valósul meg, pontosabban mobil applikációkban (Android, iPhone/iPad), amiket bárki letölthet a mobiltelefonjára. A projekt elöször ingyenesen felkínálja az első, ízelítő fejezetet, majd az olvasó kap két választási lehetőséget: vagy megveszi az egész net-könyvet minden fejezet- és befejezés-variációval együtt, vagy csak az egyes fejezeteket az olvasás előrehaladásának megfelelően. A második esetben az események fejlődésének csupán egyetlen variánsára van kilátás az olvasás során. Meg kell jegyeznünk, hogy a cselekménynek három lehetséges elágazása és

\footnotetext{
${ }^{13}$ Vjacseszlav KuRICIN, Szon o szetyi. https://www.netslova.ru/teoriya/son.html (Letöltés ideje: 2020. április 15.)

${ }^{14}$ Borisz Akunyin, Szulazsin: Poveszty, eBook Applications, 2016.

https://www.e-reading.club/bookreader.php/1047805/Akunin_-_Sulazhin.html. (Letöltés ideje: 2020. április 15.)
} 
nyolc befejezési variánsa van. Ahogyan az Android és az iOS platformjain a könyvhöz adott hivatalos tájékoztatóban írják: „A könyv cselekménye az első, bevezető fejezetből indul, és aztán az olvasó választása szerint elágazik. Ennek eredményeként nyolc különböző cselekményszálat és nyolc különbözö müfajt kaphat a kegyetlen detektívtörténettől a női regényig”. A projekt szerzője bevallja: „Vidám és érdekes dolog volt számomra ennek a nyolckarú polip-könyvnek a megírása. Olyan elbeszélésröl van szó, amely reagál az olvasó belső hangjára. Sokfélének bizonyulhat - az Ön választásától függően: édesnek, keserünek, savanyúnak, sósnak, félelmetesnek. A végén pedig hozzáférhet egy pszichológus véleményéhez, és végre megtudhatja, milyen ember is Ön." 15

Az Octopus projektben megvalósult a „nézői [és olvasói - M. Cs.] élvezetnek és átélésnek, valamint a szakértői értékelésnek az a szoros összefonódása", ${ }^{16}$ amelyet Walter Benjamin jellemzőnek tartott a tömegek müvészethez való viszonyára. Walter Benjamin éppen arról írt, hogy a média fejlődésével a „szerző és az olvasó elkülönítése kezdi elveszíteni elvi jelentőségét. Funkcionálissá válik, a köztük lévő határ a szituációtól függően így is, úgy is húzódhat - a szerzővé válás mindenki számára elérhetö lesz".17

Egy mély kutatásban, a Beszélgetés amerikai módra: Az alku diskurzusa a 19. századi amerikai irodalomban címü monográfiájában T. D. Venyegyiktova azt bizonyítja, hogy a 19. század amerikai ideálja, amely a piaci viszonyok, a politikai demokrácia és az újsütetü tömegkommunikációs rendszer erőterében született, közel áll az „alku” modelljéhez. Nyilvánvaló, hogy hasonló folyamatokat figyelhetünk meg a kortárs tömegirodalomban is, Borisz Akunyin kiadói stratégiái pedig gyakorlatilag illusztrációként szolgálnak Venyegyiktova azon elgondolásához, mely szerint

az alku modelljére épülö irodalmi kommunikációban a legfontosabb, hogy az olvasó szerepe sosem látott módon felelősségteljessé válik, majdhogynem egyenrangúvá a szerzoóvel. Rendkívüli mértékben stimulálódik az „értelmezői” iniciatíva szabadsága, habár ugyanakkor a szöveg meg is béklyózza, ami a mủ alkotó jellegủ befogadási folyamata számára bosszantóan ingadozó jelleget kölcsönöz. ${ }^{18}$

Borisz Akunyin arra a kérdésre válaszolva, hogy milyen sajátosságai vannak a szövegének, megjegyezte, hogy ez a könyv

\footnotetext{
${ }^{15}$ Uo.

${ }^{16}$ Walter Benjamin, Proizvegyenyije iszkussztva v epohu jevo tyehnyicseszkoj voszproizvogyimosztyi, Moszkva, 1996, 49.

${ }^{17}$ Uo., 44.

${ }^{18}$ T. D. Venyegyiktova, Razgovor po-amerikanszki: Diszkursz torga v szlovesznosztyi USA 19. veka, Moszkva, 2003, 245.
} 
egy új típusú szöveg prototípusa, olyan szövegé, amelyikben az olvasónak van választási lehetősége. Mint az életben. A könyv válhat végül boldoggá vagy boldogtalanná, vidámmá vagy szomorúvá. Feltételesen fogalmazva, az, hogy Anna a vonat elé ugrik-e vagy sem, az olvasótól fog függeni. Ezen kívül a szerző számára is új lehetőségek nyílnak, amilyeneket nem ad meg a papíralapú könyv: interaktivitást, multimedialitást, variativitást. Az Octopus projekt - ebbe az irányba tett lépés. ${ }^{19}$

Akunyin Szulazsinját úgy is jellemezhetjük, mint olyan kísérleti projektet, amely egyesíti magában a net-irodalom vonásait az olyan pszichológiai szövegével, amely a kísérleti alany személyiségtípusának kiderítésére irányul. Azt, hogy a könyv egyúttal tesztként is müködik, az olvasó még mindjárt az elején megtudja, amikor arról esik szó, hogy a cselekvés és az olvasás folyamán megtett választás meghatározott befejezéshez vezet, amely egyúttal az olvasónak mint kísérleti alanynak pszichológiai portréját is adja.

A játék-kisregény szüzséje a következőkben foglalható össze: a főhős (nemi hovatartozása nincs megjelölve), aki gyógyíthatatlan betegségben szenved és egy Szulazsin nevü fájdalomcsillapító gyógyszert szed, egy barátja/ismerőse, Lev Lvovics tanácsára eljár egy csoportos terápiára, ahol egy bizonyos Gromov pszichológiai segítséget nyújt a halál küszöbén álló embereknek. Az egyik terápiás foglalkozás alkalmával megjelenik a helyiségben egy titokzatos hölgy, aki azért jött, hogy elbúcsúzzon Gromovtól. Távozása előtt pillantást vet még a főhősre, akiben megérzi, hogy a felszólítására esetleg követi öt. Ezzel ér véget a Szulazsin első fejezete, és az olvasó a továbbiakban választásra kap lehetöséget: vagy követi az ismeretlen hölgyet, vagy ott marad a terápiás foglalkozáson. A második fejezetben, az olvasó választásától függöen, a föhös vagy egy férfi, Nyikolaj - ha a hös követte a titokzatos hölgyet -, vagy egy nő, Tonya - ha a hős ott maradt a foglalkozáson. A továbbiakban az olvasó kap még néhány lehetőséget a szüzsé megválasztására, aminek köszönhetően kialakul a müfaj (akcióregény, detektívtörténet, thriller, nőregény, pszichológiai elbeszélés, stb.) és az adott történet befejezése is. A Szulazsin elolvasását követően, attól függően, hogy az olvasó milyen cselekményvezetési vonalakat választott, kap egy pszichológiai diagnózist is: „Azt a döntési láncolatot, amelyet Ön a cselekmény elágazásaiban hozott, az Ön tudatalattijának képlete és személyiségének összetétele határozta meg. (Már persze ha nem csak találomra kattintott rá az ikonra.) Mindennek eredményeként kirajzolódott egy müfaj és egy befejezés, amely a következőket teszi lehetővé feltételezni Önről." ${ }^{20}$ És az olvasót végül az öt pszichológiai következtetés valamelyikre várja. Annak ellenére, hogy a pszichológiai következtetések meglehetősen általánosítók

19 Tarasz Miscsenko, Intervju sz B. Akunyinim. https://itc.ua/articles/sulazhin-novaya-kniga-borisaakunina-vyihodit-v-vide-igrovogo-prilozheniya-intervyu-s-avtorom-i-razrabotchikami/ (Letöltés ideje: 2020. április 15.)

${ }^{20}$ AKUnYin, i. m. 
és nem éppen eredetiek, szerepeltetésük a játék-könyv végén a szerző bizonyos újító szándékáról tanúskodik: az orosz irodalomban nincs hasonló projekt, amely magába foglalná egy könyv, egy quest és egy pszichológiai elemzés elemeit.

Meg kell jegyeznünk, hogy Akunyin új müve az olvasóktól igencsak ellentmondásos véleményeket kapott. Egyesek megállapították, hogy az elbeszélés pszichologizáló jellegének köszönhetően az olvasónak olyan érzése támad, mintha ő maga is részt venne egy pszichológiai foglalkozáson. Mások szkeptikusan viszonyultak mind a regény tartalmi részéhez, mind a mü nyelvezetéhez, sokan túlságosan primitívnek, az Akunyin-müvekkel nem összhangban állónak ítélték meg az elbeszélői stílust, a szüzsét pedig unalmasnak és rosszul átgondoltnak vélték. Ugyanakkor minden olvasó pozitíven ítélte meg a mü funkcionális részét, magát a mobil applikációt: érdekes a szöveg, színes a képi megformáltság, van benne sok rajz, jó a Borisz Grebenscsikovtól származó zenei kíséret és kényelmes az alkalmazás használata. ${ }^{21}$

Érdekesnek tünik az a tény, hogy az interaktív müfajokban született hasonló, népszerü külföldi projekteket rendszerint nem írók, hanem okostelefonok applikációinak kidolgozói készítik, ami külön értéket képvisel a Szulazsin esetében, és elsősorban mint olyan irodalmi projektet emeli ki a többi közül, amely az interaktív regény müfajában smartphone-on olvasásra készült. Fontos megjegyeznünk, hogy az Akunyin-féle Szulazsin irodalmi alkotás, amely a játék-könyv kánonja szerint készült, amelyben a szépirodalmi szöveg bizonyos mennyiségü, tetszőlegesen megválasztható fragmentumokból épül fel. Minden egyes történet logikusan befejezett szépirodalmi szövegnek tekinthető. Viszont ha a könyvet teljes egészében, minden szüzsé-variációjával együtt elolvassuk, akkor a Szulazsint különféle müfajú elbeszélésekből álló elbeszéléskötetnek is tarthatjuk.

Christiane Paul a Digitális müvészet címü könyvében részletesen leírja, hogyan nyitottak új lehetőségeket a smartphone-ok és a tabletek, valamint a hozzájuk tartozó alkalmazások a virtuális valóság művészi értelmezéséhez. ${ }^{22}$ Akunyin projektjének fontos sajátossága, hogy elismeri az irodalmi szöveg létmódjának új lehetőségeit. Az ilyen szövegek elemzésének eszközeit pedig az „e-filológia” dolgozhatja ki, amelyről Mihail Epstejn azt írja, hogy

különleges humántudomány, a netes szövegekkel való foglalkozás elmélete és gyakorlata. Lehet nevezni textonicsnak is, egyesítve az elnevezésben a „text” és az „elektronics” szavakat. Ha a hagyományos textológia a filológiának olyan ága, amely a papíralapú szövegek tanulmányozásával és kiadásával foglalkozik, akkor a textonics a filológia olyan ága, amely a digitális szövegek tanulmányozásával és szervezödésével foglalkozik. A textonics nem más, mint

\footnotetext{
${ }^{21}$ Az olvasói véleményeket lásd: https://www.livelib.ru/work/1001607120/reviews-sulazhin-boris-akunin (Letöltés ideje: 2020. április 15.)

${ }^{22}$ Christiane Paul, Cifrovoje iszkussztvo, Moszkva, Ad Marginem Pressz, 2017, 238.
} 
az Internet és a komputertechnika minden lehetöségének felhasználása új jelcsoportok létrehozására, az intellektuális alkotás új müfajainak kidolgozására, a már létező szövegmasszívumok reorganizálására és átértelmezésére. ${ }^{23}$

A kortárs irodalom nyilvánvalóan digitális irányba is fejlődni fog, felhasználva az okostelefonokat és alkalmazásokat, amelyek már rég a társadalom elválaszthatatlan részévé váltak. Az Octopus projekt lerakta az interaktív regény új formájának alapját - e müfaj további alakulásának vizsgálata pedig még elöttünk áll.

GoRETITy József fordítása

\author{
Marija Csernyak \\ professzor \\ Szentpétervári A. I. Herzen Állami Pedagógiai Egyetem \\ ma-cher@yandex.ru \\ The Tendencies of Russian Prose Literature in the Digital Age: \\ The Question of Interactive Literature
}

\begin{abstract}
The paper focuses on the analysis of e-literature, which is also present in contemporary Russian literature. It defines e-literature as a modern cultural phenomenon which heavily builds upon the readers' activity and choices, as well as interactivity. It reviews the characteristics of e-literature and its place in today's literature, primarily based upon Mikhail Epstein's theories. The article introduces the genre diversity and potentials of e-literature through one of the most characteristic works in Russian e-literature, Boris Akunin's Octopus project.
\end{abstract}

Keywords: digital age, e-literature, variativity, interactivity, game novel

DOI: 10.37415/studia/2020/1-2/29-37.

Open Access: Creative Commons Attribution 4.0 International (CC BY 4.0) (c) (i)

${ }^{23}$ Epstejn, i.m., 16. (kiemelés tőlem) 